\title{
Mechanical feasibility of using red mud as filler in asphalt mixtures to improve permanent deformation
}

\author{
Mayara Sarisariyama Siverio Lima ${ }^{1}$, Liseane Padilha Thives ${ }^{2}$ \\ 1Departamento de Engenharia Civil, UFSC, mayarasiverio@gmail.com \\ 2Departamento de Engenharia Civil, UFSC, liseane.thives@ufsc.br
}

\section{Recebido:}

24 de setembro de 2018

Aceito para publicação:

29 de maio de 2019

Publicado:

15 de maio de 2020

Editor de área:

Francisco Thiago Aragão

\section{Keywords:}

Red mud,

Permanent deformation, Filler.
DOI:10.14295/transportes.v28i2.1847

\begin{abstract}
Red mud is a solid residue that results when bauxite ore is processed to obtain alumina (aluminum oxide $-\mathrm{Al}_{2} \mathrm{O}_{3}$ ), the main chemical compound to produce aluminum. Brazil has a wide reserve of bauxite in Pará State and the ore is processed in large scale. However, in the country red mud is stored inadequately in the environment. Pará is situated in northern region of Brazil and presents high temperature throughout the year. The elevated traffic volume and the high temperatures contributed to the early appearing of defects in the flexible asphalt pavement surfaces. This laboratory study aims the introduction of the red mud as filler in dense asphalt mixtures to improve the permanent deformation resistance. Asphalt mixtures with $3 \%, 5 \%$ and $7 \%$ of red mud (range between 0.02 to 2,800 micrometers) were produced. A conventional mixture with $7 \%$ stone powder filler (maximum diameter of $0.075 \mathrm{~mm}$ ) was used as reference. Permanent deformation resistance of the mixtures was evaluated through French Rutting Tester. As a result, the mixture with $5 \%$ red mud presented better resistance that obtained at 30,000 cycles, $3.5 \%$ of rutting percentage depth. The asphalt mixtures with red mud presented good performance, with reduction of the permanent deformation of 12.63 to $42.62 \%$ in relation to reference mixture. Red mud as filler in asphalt mixtures is a viable option to reuse this waste, as well as being an environmentally friendly alternative.
\end{abstract}

\section{RESUMO}

A lama vermelha é um resíduo sólido resultante do processamento do minério de bauxita para obtenção da alumina (óxido de alumínio $-\mathrm{Al}_{2} \mathrm{O}_{3}$ ), que é o principal composto químico para produzir alumínio. O Brasil possui uma grande reserva de bauxita no estado do Pará e o minério é processado em larga escala. No entanto, no país, a lama vermelha tem sido armazenada inadequadamente no meio ambiente. O Pará está situado no norte do Brasil e apresenta alta temperatura durante todo o ano. $O$ elevado volume de tráfego e as altas temperaturas contribuíram para o surgimento precoce de defeitos nos revestimentos asfálticos dos pavimentos flexíveis. Este estudo laboratorial visa à introdução deste resíduo como fíler em misturas asfálticas densas. Para tanto, foram produzidas misturas de asfalto com 3\%, 5\% e 7\% de lama vermelha (tamanho nominal entre 0,02 a 2.800 micrometros). Como referência, foi produzida uma mistura convencional com $7 \%$ de fíler de pó de pedra (tamanho nominal inferior a 0,075 mm). A resistência à deformação permanente das misturas foi avaliada através do simulador de tráfego francês. Como resultado, a mistura com $5 \%$ de lama vermelha apresentou o meIhor desempenho à deformação permanente e obteve, aos 30.000 ciclos, a porcentagem de afundamento de 3,5\%. As misturas asfálticas com lama vermelha apresentaram bom desempenho, com redução da deformação permanente de 12,63 a 42,62\% em relação à mistura de referência. A lama vermelha como fíler em misturas asfálticas mostrou ser uma opção viável para reutilizar este resíduo, além de ser uma alternativa ecologicamente adequada. 


\section{INTRODUCTION}

Red mud is the solid waste residue from bauxite ores process with caustic soda for alumina $\left(\mathrm{Al}_{2} \mathrm{O}_{3}\right)$ production (Sutar et al., 2014). In general, for each tonne of alumina produced, 0.3 to 1.5 tonnes of red mud can be generated (Komnitsas et al., 2004; Hildebrando et al., 2013). These values are referred to as dry-mass. The variations depend on the ore composition (Li, 1998). The production of primary aluminum is composed of the following phases: (1) mining, in which the bauxite is removed and treated; (2) processing, which results in alumina; (3) reduction, which refers to the electrolytic process that originates the metallic aluminum.

Currently, alumina is produced from bauxite through the Bayer process. The Bayer process was discovered in 1887 by Karl Bayer. He found that aluminum hydrate can be precipitated by carbon dioxide, $\mathrm{CO}_{2}$ from an alkaline solution of sodium aluminate (Tabereaux, 2010). This is the process of refining alumina from bauxite (aluminum ore containing $30-50 \%$ of hydrated aluminum oxide) by selective extraction of pure aluminum oxide dissolved in sodium hydroxide (Li, 1998). From this process, the major by-product is converted to a slurry waste, named red mud, which contains $15 \%$ to $40 \%$ solids and is very alkaline (pH 11.0 to 12.5). In the processing phase, the Bayer process is applied and it is composed by these four main stages: (1) digestion, (2) clarification, (3) precipitation, (4) calcination (Li, 1998; Sampaio et al., 2005; Habashi, 2005; Sutar et al., 2014). The red mud is the residue resulting from the clarification stage, as shown in Figure 1.

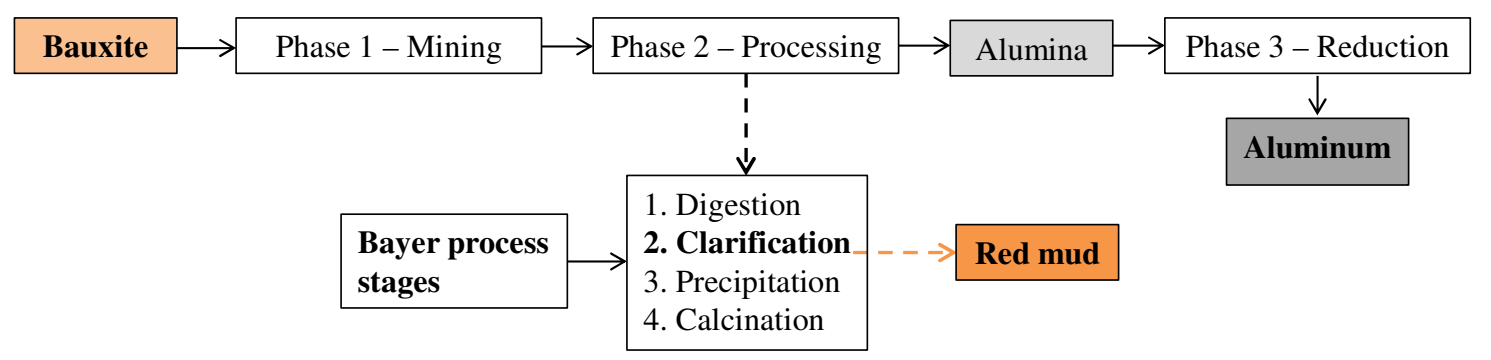

Figure 1. Red mud obtainment as from bauxite processing

In the clarification phase, red mud is separated from a liquor rich in aluminum hydroxide (supernatant), through thickening and filtration techniques. The material originated from the digestion process is transferred to the thickeners in which, under action of flocculants, the residue is separated by sedimentation. The red mud coming from the decanters pass through washing and filtration processes and then is stored (Mccormick et al., 2000; Habashi, 2005). However, during the washing process, part of the sodium hydroxide (caustic soda) added to the process cannot be removed, which results in the high alkalinity and hazardousness of the residue. First, the bauxite residue (red mud) slurry is then pumped to a large on-site impoundment area commonly known as red mud lake. After that, the red mud drying occurs in the open air (Tabereaux, 2010). Due to the alkaline nature and the presence of heavy metals (án jenic, cadmium, nickel, zinc, lead, copper, chromium, vanadium, iron, gallium, phosphorus, manganese, magnesium, thorium, and niobium), red mud is considered a hazardous waste (Hind et al., 1999; Brunori et al., 2005; Bertocchi et al., 2006). Residue is usually placed off in the landfills and the sodium hydroxide content can contaminate the adjacent and the storage areas (Hind et al., 1999; Menzi et al., 2010). The main methods used for red mud disposal are classified into groups, namely: (i) seawater discharge, (ii) lagooning, (iii) dry stacking, (iv) dry disposal (Wang et al., 2008; Power et al., 2009), as presented in Table 1. 
Table 1 - Advantages and disadvantages of red mud disposal methods

\begin{tabular}{|c|c|c|c|}
\hline Method & Description & Advantages & Disadvantages \\
\hline $\begin{array}{l}\text { Seawater } \\
\text { discharge }\end{array}$ & $\begin{array}{l}\text { Residue is disposed directly } \\
\text { into the sea, via a pipeline } \\
\text { which takes the slurry well off- } \\
\text { shore for discharge into the } \\
\text { deep ocean. Is important to } \\
\text { observe that, despite red mud } \\
\text { is a hazardous material, in } \\
\text { some locals in the world, this } \\
\text { residue is discharged into the } \\
\text { deep ocean. }\end{array}$ & $\begin{array}{l}\text { Eliminates the need for } \\
\text { maintenance and rehabilita- } \\
\text { tion of storage areas and } \\
\text { potential environmental im- } \\
\text { pacts related to leaching of } \\
\text { heavy metals. }\end{array}$ & $\begin{array}{l}\text { Potential destruction of ma- } \\
\text { rine ecosystems and release } \\
\text { of toxic metals in marine envi- } \\
\text { ronment; long and short term } \\
\text { effects unknown. }\end{array}$ \\
\hline Lagooning & $\begin{array}{l}\text { Residue is pumped into land- } \\
\text { based ponds. Such ponds may } \\
\text { be formed within natural de- } \\
\text { pressions using dams and } \\
\text { other earthworks to ensure } \\
\text { secure containment. }\end{array}$ & $\begin{array}{l}\text { Lower installation cost and } \\
\text { minimizes dust from the } \\
\text { waste. }\end{array}$ & $\begin{array}{l}\text { Requires granting of substan- } \\
\text { tial land areas for storage; loss } \\
\text { of sodium and alumina pre- } \\
\text { sent in waste. }\end{array}$ \\
\hline Dry stacking & $\begin{array}{l}\text { Residue is thickened to a paste } \\
\text { ( } 48 \text { to } 55 \% \text { solids) prior to dis- } \\
\text { charge. The paste is pumped } \\
\text { and transported in pipes and } \\
\text { discharged progressively in } \\
\text { thin layers which are allowed } \\
\text { to dewater and air-dry before } \\
\text { being overlain with the next } \\
\text { layer. }\end{array}$ & $\begin{array}{l}\text { Reduces the need for contain- } \\
\text { ment structures and the po- } \\
\text { tential of soil and groundwa- } \\
\text { ter contamination }\end{array}$ & $\begin{array}{l}\text { Dry cell surfaces are subject to } \\
\text { dust, and mitigation proce- } \\
\text { dures are needed; significant } \\
\text { compaction makes it difficult } \\
\text { to establish the vegetation. }\end{array}$ \\
\hline Dry disposal & $\begin{array}{l}\text { Residue is filtered to a dry } \\
\text { cake (> } 65 \% \text { solids). The dry } \\
\text { residue cake is carried by truck } \\
\text { or conveyor to the disposal } \\
\text { site, where it is dumped with- } \\
\text { out further treatment. }\end{array}$ & $\begin{array}{l}\text { Area needed for storage is } \\
\text { minimized; the low alkaline } \\
\text { content of the material favors } \\
\text { the soil rehabilitation and re- } \\
\text { forestation. }\end{array}$ & $\begin{array}{l}\text { Requires the granting of } \\
\text { enough land area for storage; } \\
\text { requires the installation and } \\
\text { operation of a filtration plant. }\end{array}$ \\
\hline
\end{tabular}

All methods present advantages and disadvantages; however, reinsert residue into the production chain is a most adequate practice in environmental terms. Even when stored correctly, industrial wastes such as red mud represent a threat to fauna and flora, being able to cause environmental damage, such as contamination of surface and groundwater effluents, and affect health of neighboring populations (Antunes et al., 2011).

Depending on the time of exposure to the environment, red mud suffers variations of its chemical composition. Yang and Xiao (2008) indicated that red mud stored for 10 years presented a loss of its capacity of combustion due to carbonation of compounds such as calcium aluminate and dicalcium silicate.

As consequence of the red mud inadequate disposal, several environmental accidents occurred in the world. The most serious accidents occurred in Brazil (in 2003, 2004, 2009, 2018) and in Hungary (in 2010). The environmental disasters represented a world great concern and contributed to the researchers increased the studies in order to search for alternatives to reuse and reinsertion of the red mud in the production chain.

Brazil has a large reserve of bauxite and is the third largest producer of this ore in the world (U.S. Geological Survey, 2016). The Brazilian State Pará has the major reserves of this ore and in 2015 produced 90.9\% (32.2 Mt of bauxite) of the national total (Brazil, 2016). However, in the country, the recycling of red mud is incipient and this hazardous residue is still deposited inadequately in the environment. 
Several researches have studied alternatives to red mud reuse and reinsertion in the production chain (Kavas, 2006; Yang et al., 2009; Hanumanth et al., 2012; Jitsangiam and Nikraz, 2013). Although the red mud has been studied in some researches, it is application as filler in asphalt mixtures is still limited.

The asphalt mixtures applied as flexible pavement surfaces are composed of coarse and fine aggregates, filler (material with at least 65\% passing in the $75 \mu \mathrm{m}$ sieve) and asphalt. The filler incorporated into the asphalt mixture can improve rheological, thermal and water sensitivity performance, having void filling functions and increasing asphalt viscosity. Also, the presence of filler tends reduce the thermal susceptibility, the increase of the strength and the resistance to permanent deformation (FHWA, 2001).

The interaction powder/asphalt is an important factor to be considered in asphalt mixtures characterization, once it depends on the chemical composition of the asphalt and the characteristics of the filler, such as mineralogical composition, surface texture and specific surface. The powder/asphalt ratio indicates the absence of free asphalt, which expresses the amount of asphalt to coat aggregates. The higher is this ratio, the thinner is the asphalt film that involves the aggregates and difficult the adhesion between them. The ideal powder/asphalt ratio for dense asphalt mixtures is from 0.8 to 1.6 (Motta and Leite, 2000; FHWA, 2001; Wesseling et al., 2003).

The Brazilian highways have shown early defects due to the high rate of heavy traffic along with high temperatures. One of the main defects verified is the permanent deformation on the asphalt mixture surface. In high-temperature conditions, because of the repeated effect of the wheel rolling, load stress will exceed the plastic limit of the asphalt mixture, and then flow deformation will accumulate to form ruts, named permanent deformation (Yang e Ning, 2011). The permanent deformation is a defect that occurs in the pavements and affects the safety of their users, reducing the rolling comfort and increasing the maintenance costs. Permanent deformation results from the accumulation of small amounts of irreparable strain as a result of repeated loads applied to the pavement (Sousa et al., 1994; Tigdemir, 2008).

Permanent deformation in a pavement often develops gradually with increasing numbers of applications, typically appearing as longitudinal depressions in the wheel paths sometimes accompanied by small upheavals to the sides. The main problem of permanent deformation arises from excessive traffic consolidation on the upper layer of the pavement, plastic deformation due to insufficient mixture stability and also instability caused by stripping of asphalt below the riding surface of the pavement. Test procedures have been conducted to evaluate and predict rutting in a laboratory. One of these is the wheel tracking test, which simulates conditions similar to pavement conditions in service to obtain rut depth under a specified load cycle (Nevelt and Thanfold, 1988; Brow et al., 2001; Ahmad et al., 2011; Xu et al., 2013).

The Pará State is situated in the Northern Brazil and presents high temperature over the year. The elevated traffic volume and the high temperatures of the region have contributed to the early appearance of defects in the road pavement, especially in the asphalt surfaces. In this context, this laboratory study aims the introduction of the red mud as filler in dense asphalt mixtures to improve the permanent deformation resistance.

\section{METHODOLOGY}

In this study the use of red mud as filler in asphalt mixtures was evaluated in relation to permanent deformation at state temperatures. Figure 2 shows the flowchart of the experimental methodology. 

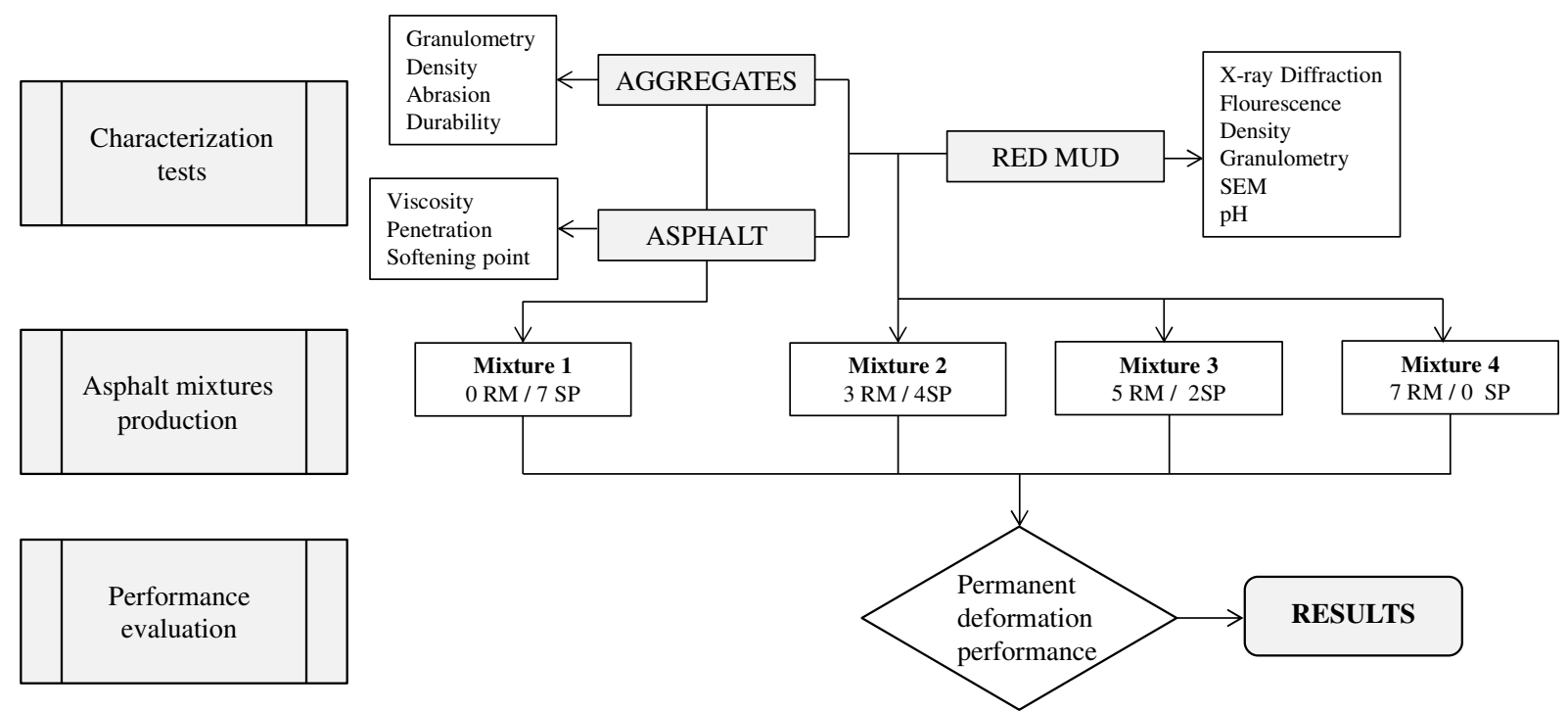

Figure 2. Flowchart of the experimental methodology

In the experimental methodology, dense asphalt mixtures were produced according to the Brazilian specification DNIT 031/06, Grade C (Brasila, 2006). The asphalt CAP-50/70, classified by penetration grade (Brasilb, 2006), granite aggregates, and filler (red mud stone powder) were used. Prior carrying out of the mechanical tests, material characterization tests were conducted (asphalt, aggregates and red mud).

The asphalt mixtures were produced with a total of 7\% filler, being 3\%, 5\% and 7\% red mud (Mixture 2 - 3RM / 4SP; Mixture 3- 5RM / 2SP and Mixture 4 - 7RM / 0SP, respectively). A mixture with $0 \%$ red mud and 7\% stone powder (Mixture 1 - 0RM / 7SP) was used as reference. The mixtures were designed according to the Superior Performing Asphalt Pavements (SUPERPAVE@) method for high traffic volume. The performance to permanent deformation was evaluated through the wheel tracker test, in the French Rutting Tester at $60^{\circ} \mathrm{C}$, according to NF-P 98-253-1 (AFNOR, 1993).

\section{RESULTS}

This section presents the materials (aggregates, red mud, and asphalt) characterization results. The granulometric curve used for asphalt mixtures production (with and without red mud), the volumetric parameters from design and the results of the permanent deformation tests are also shown and discussed.

\subsection{Materials characterization}

\subsubsection{Aggregates}

The granulometric analysis of the aggregates was carried out according to the Brazilian standard DNER ME 083/98 (Brasil, 1998) and is illustrated in Figure 3.

The granite aggregates come from a quarry located in Santa Catarina State, Brazil. Gravel 1 (maximum diameter of $3 / 4$ inches), gravel 0 (maximum diameter of $3 / 8$ inches) and stone powder (maximum diameter of $4.75 \mathrm{~mm}$ ) were used for the asphalt mixtures composition. Aggregates characterization tests (granulometry, density, abrasion and durability) were carried out and are presented in Table 2. The results showed that the aggregates fit according to Brazilian specifications (Brasila, 2006) and were able to produce asphalt mixtures. 


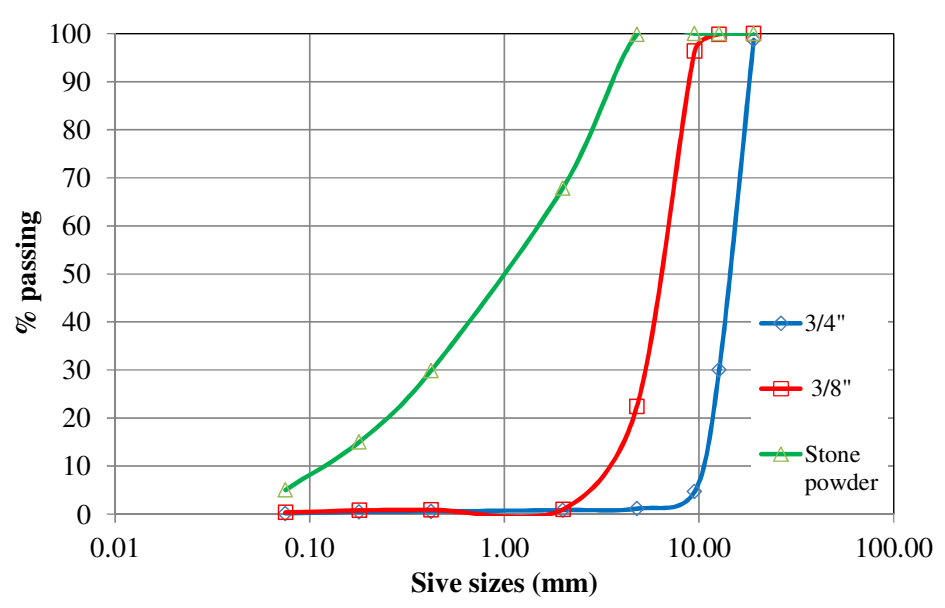

Figure 3. Aggregates granulometric distribution

\subsubsection{Asphalt}

The asphalt used for the production of the mixtures was the Brazilian asphalt CAP-50/70, classified by penetration. The asphalt characterization was performed by means of softening point, penetration and viscosity tests. The asphalt fit into Brazilian specifications (Brasilb, 2006) and the results are presented in Table 3.

Table 2 - Aggregates characterization tests results

\begin{tabular}{llccc}
\hline Tests & Standard & $3 / 8$ inches & $\begin{array}{c}\text { Aggregates } \\
3 / 4 \text { inches }\end{array}$ & Stone powder \\
\hline Apparent specific gravity $\left(\mathrm{G}_{\mathrm{sa}}\right)$ & ASTM C 127/ & 2.774 & 2.7748 & 2.717 \\
Bulk specific gravity $\left(\mathrm{G}_{\mathrm{sb}}\right)$ & DNER ME 084/ & 2.740 & 2.701 & - \\
Absorption (\%) & DNER ME 085 & 0.351 & 0.521 & - \\
Los Angeles abrasion (\%) & ASTM C 131 & 20.70 & 21.70 & - \\
Soundness (\%) & ASTM C 88 & 0.20 & - & - \\
\hline
\end{tabular}

Table 3 - Aggregates characterization tests results

\begin{tabular}{llll}
\hline Tests & Standard & Specifications $^{\mathbf{3}}$ & Results \\
\hline Softening point ${ }^{1}(\mathrm{o}$ C) & ASTM D 36 & 45 (min.) & 49.5 \\
Penetration (100g; 5s; 25으) & ASTM D 5 & $50-70$ & 64.0 \\
Apparent viscosity ${ }^{2}(\mathrm{cP})$ & & & \\
$135^{\circ} \mathrm{C}, \mathrm{SP} 21,50 \mathrm{rpm}$ & & 141 (min.) & 308.7 \\
$150^{\circ} \mathrm{C}, \mathrm{SP} 21,60 \mathrm{rpm}$ & ASTM D 4791 & 50 (min.) & 157.5 \\
$177^{\circ} \mathrm{C}, \mathrm{SP} 21,100 \mathrm{rpm}$ & & $30-150$ & 63.2 \\
\hline${ }^{1}$ Ring and ball method; ${ }^{2}$ Brookfield viscometer; ${ }^{3}$ Asphalt specifications are given in DNIT \\
031/06 - ES (Brasilb, 2006).
\end{tabular}

\subsubsection{Red mud}

The red mud comes from Barcarena city (Pará State). The mineralogical analysis was carried out using an X-ray diffractometer. The test was performed between angles $2 \theta$ of $5^{\circ}$ to $90^{\circ}$, with pitch of 0.05 and 1 second in counting time. Figure 4 presents the results and shown phases of hematite $\left(\mathrm{Fe}_{2} \mathrm{O}_{3}\right)$, anatase $\left(\mathrm{TiO}_{2}\right)$, quartz $\left(\mathrm{SiO}_{2}\right)$, karelianite $\left(\mathrm{V}_{2} \mathrm{O}_{3}\right)$, gibbsite $\left.\left(\mathrm{Al}(\mathrm{OH})_{3}\right)\right)$ coming from the bauxite and sodalite were detected. Hematite, anatase, quartz, gibbsite and sodalite are substances that do not present health hazard, except in concentrations higher than those 
listed in the Brazilian standard NBR 10.004/2004 (ABNT, 2004). Karelianite $\left(\mathrm{V}_{2} \mathrm{O}_{3}\right)$, or vanadium trioxide, in presence of moisture (humidity), may oxidize and transform into vanadium pentoxide $\left(\mathrm{V}_{2} \mathrm{O}_{5}\right)$, which, in high concentrations, presents hazard to the residue.

The morphological structure of the material was evaluated by a scanning electron microscope (SEM). In Figure $5_{(a)}$, the micrograph with magnification of 1,000x, the red mud presented a spongious structure that characterizes the high specific surface of the material and; in Figure 5 (b), with a magnification of 5,000x, it was observed agglomerates of particles of size inferior to $5 \mu \mathrm{m}$ with irregular granulometric distribution.

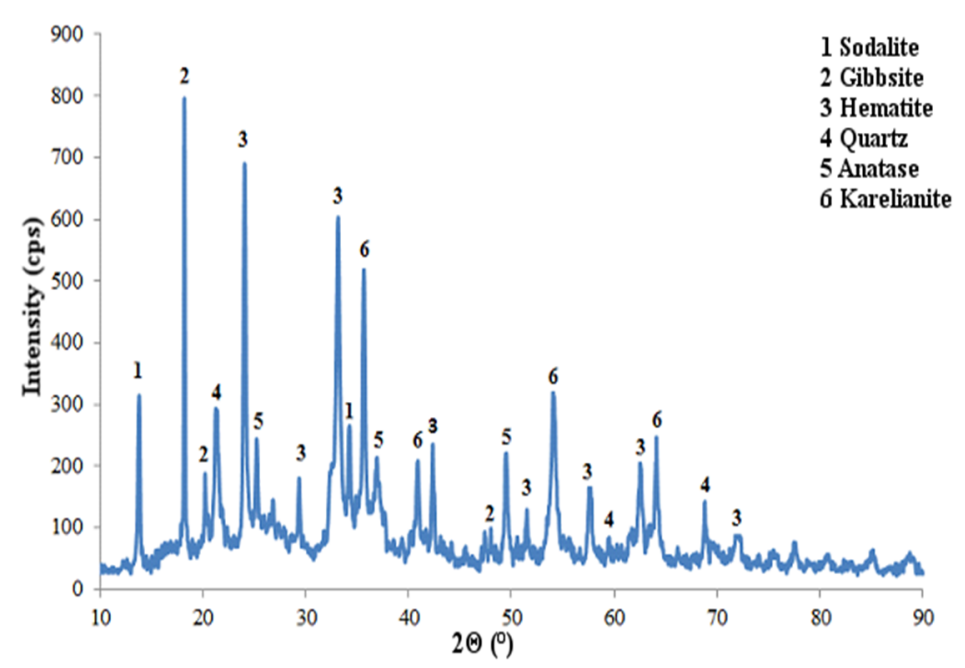

Figure 4. Red mud diffractogram

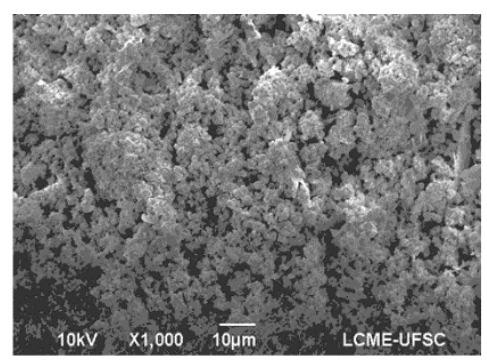

(a)

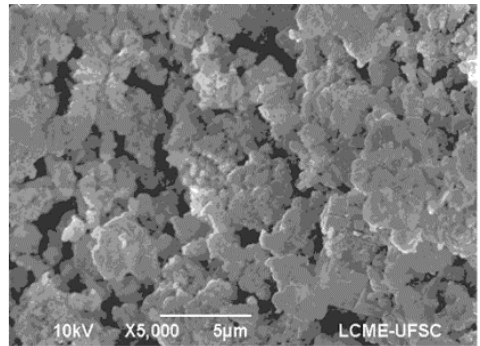

(b)

Figure 5. Red mud micrographs (a) Magnification of 1,000x (b) magnification of 5,000x

The microscopic characterization of the material was performed by energy dispersive X-ray spectrometry (Shimadzu Energy Dispersive X-ray fluorescence spectrometer - EDX) that provided the composition of the chemical elements in the red mud, presented in Table 4, that also, shows the compounds present in the red mud that were quantified by a.

The granulometry of the red mud was determined in a laser particle analyzer (MICROTAC model S3500), with a detection range of 0.02 to 2,800 micrometers $(\mu \mathrm{m})$. From the results presented in Figure 6, around 85\% of the particles had a diameter in the range of $0.4 \mu \mathrm{m}$ to $60 \mu \mathrm{m}$, being $20 \%$ the clay fraction $(<2 \mu \mathrm{m})$ and $65 \%$ the silt fraction $(2 \mu \mathrm{m}-60 \mu \mathrm{m})$, according to the Brazilian classification (ABNT, 1995). From Figure 6, also was observed that $15 \%$ of the particles presented a grain size of $60 \mu \mathrm{m}$ to $200 \mu \mathrm{m}$ range that is characteristic of fine sand granulometry. The presence of particles larger than $40 \mu \mathrm{m}$ tends to fill the voids of the aggregates and 
particles smaller than $20 \mu \mathrm{m}$ mix with the binder, altering the viscosity, softening point and thermal susceptibility ( $\mathrm{Li}, 2014$ ). Thus, as $70 \%$ of the grains of red mud presented a grain size of less than $20 \mu \mathrm{m}$, it is possible that this material is incorporated to the asphalt and altered its rheological properties.

Table 4 - Elements and compounds measured in the red mud

\begin{tabular}{cc|cc}
\hline \multicolumn{2}{c|}{ Red mud elements } & \multicolumn{2}{c}{ Red mud chemical compounds } \\
Elements & Percentage by weight & Compounds & Percentage (\%) \\
\hline Oxygen (O) & 25.94 & Alumina $\left(\mathrm{Al}_{2} \mathrm{O}_{3}\right)$ & 35.47 \\
Silica (Si) & 22.35 & Iron (III) oxide $\left(\mathrm{Fe}_{2} \mathrm{O}_{3}\right)$ & 31.45 \\
Aluminium (Al) & 15.83 & Silica $\left(\mathrm{SiO}_{2}\right)$ & 12.68 \\
Carbon (C) & 15.08 & Titanium dioxide $\left(\mathrm{TiO}_{2}\right)$ & 5.84 \\
Titanium (Ti) & 9.30 & Lime $(\mathrm{CaO})$ & 1.81 \\
Sodium (Na) & 5.22 & Vanadium pentoxide $\left(\mathrm{V}_{2} \mathrm{O}_{5}\right)$ & 0.20 \\
Iron (Fe) & 3.78 & Manganese $(\mathrm{II})$ oxide $(\mathrm{MnO})$ & 0.13 \\
Calcium (Ca) & 2.50 & Carbon dioxide $\left(\mathrm{CO}_{2}\right)$ & 12.40 \\
\hline
\end{tabular}

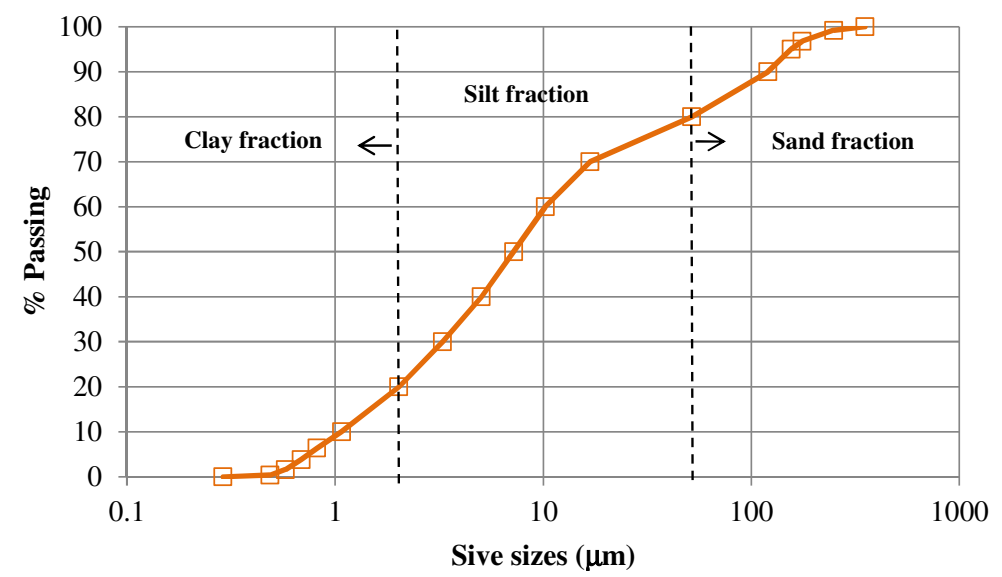

Figure 6. Red mud granulometric distribution

The specific surface, calculated by the Vogt equation, resulted in $119.0 \mathrm{~m}^{2} / \mathrm{kg}$. The red mud presented a pH of $10.25 \pm 0.05$. According to the Brazilian standard NBR 10.004/2004 (ABNT, 2004), the waste is considered corrosive when the value is in the range $12.5 \leq \mathrm{pH} \leq 2.0$. However, a $\mathrm{pH}$ above 7.0 gives the residue a basic character, so that the surface of the residue becomes electrically negative, which may influence the asphalt-aggregate adhesiveness.

\subsection{Asphalt mixtures production}

Asphalt mixtures were produced with red mud as filler in three percentages $(3 \%, 5 \%$, and $7 \%)$. Another asphalt mixture was produced with $7 \%$ of stone powder (filler). This mixture with stone powder was the reference. The granulometric curve was established according to the Grade $C$ of the Brazilian standard (Brasila, 2006) as presented in Figure 7. The results of asphalt mixtures design are shown in Table 5.

From Table 5, observed that the mixtures did not achieve the minimum VMA value according Brazilian specification. As a result, this had influence in other parameters, such as the relation $\mathrm{P} / \mathrm{A}$ and in the asphalt content. Despite the asphalt mixtures with red mud contain more fine particles that a conventional mixture, the asphalt contents were low. Al-Shamsi et al. (2017) produced mixtures varying the type of fine aggregates and obtained VMA values inferior to the 
limits. They concluded that lower VMA led to lower effective asphalt content, which in turn reduced the asphalt film thickness. Chadboum et al. (1999) assert that, in general, aggregate gradations that deviate from the maximum density line in the fine direction did not increase the VMA. The generation of fines can be caused by aggregate degradation due to aggregate handling during loading, hauling, mixing, and construction. Adequate VMA in a mixture is an important part of the mix design which must be met. A minimum VMA requirement specified for asphalt mixtures based on nominal maximum aggregate size may be not suitable. In this way, fineness modulus and crushed coarse and fine aggregate content may be much more strong indicators of critical VMA. Current minimum VMA requirements may exclude mixtures that present good perform (Hislop and Coree, 2000). The lower VMA values obtained is this study can be resulted from the red mud particle sizes. In this case, micro size particles can be acted as an aggregate degraded as Chadboum et al. (1999) concluded.

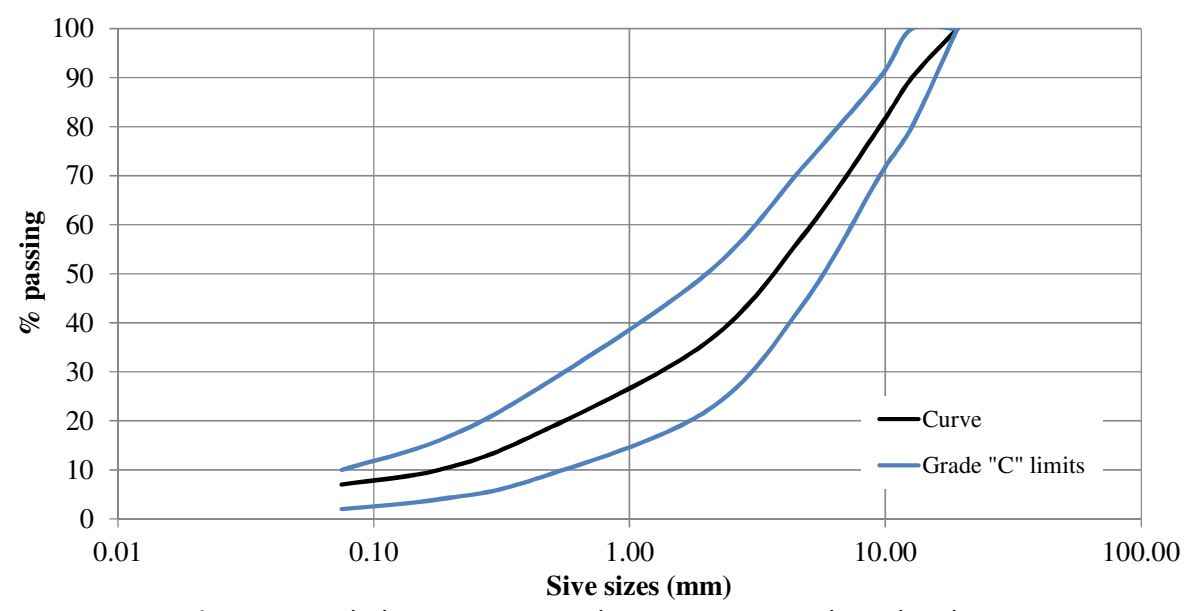

Figure 7. Asphalt mixtures granulometric curve and Grade $\mathrm{C}$ limits

Table 5 - Asphalt mixtures volumetric parameters

\begin{tabular}{lccccc}
\hline Parameters & DNIT & \multicolumn{3}{c}{ Mixtures } \\
& 031/06 & ORM / 7SP & 3RM / 4SP & 5RM / 2SP & 7RM / OSP \\
\hline Filler - stone powder (\%) & - & 7 & 4 & 2 & 0 \\
Filler - red mud (\%) & - & 0 & 3 & 5 & 7 \\
Asphalt content (\%) & - & 4.7 & 4.6 & 4.5 & 4.4 \\
$\mathrm{G}_{\mathrm{mm}}{ }^{1}\left(\mathrm{~g} / \mathrm{cm}^{3}\right)$ & - & 2.551 & 2.558 & 2.559 & 2.557 \\
$\mathrm{G}_{\mathrm{mb}}{ }^{2}\left(\mathrm{~g} / \mathrm{cm}^{3}\right)$ & - & 2.448 & 2.460 & 2.455 & 2.455 \\
Voids content (\%) & $3-5$ & 4.0 & 4.0 & 4.0 & 4.0 \\
Voids in the mineral aggregate (VMA) min. & 15 & 14.1 & 13.4 & 12.6 & 12.4 \\
Asphalt-void ratio (RBV) & $75-82$ & 70.9 & 71.7 & 67.6 & 67.8 \\
Powder-asphalt ratio (P/A) & - & 1.49 & 1.52 & 1.55 & 1.59 \\
\hline
\end{tabular}

${ }^{1} G_{m m}-$ Maximum specific mass measured; ${ }^{2} G_{m b}-$ Apparent specific mass.

The asphalt mixtures design was performed according to the standards AASHTO M 323 (AASHTO, 2011) and AASHTO R 35-12 (AASHTO, 2012) in specimens with diameter of $150 \mathrm{~mm}$ for $\mathrm{N}_{\text {project }}$ of 125 revolutions. The production temperatures, established from the asphalt viscosity curve, were $148^{\circ} \mathrm{C}$ (for mixing) and $137^{\circ} \mathrm{C}$ (for compaction). The heating temperature of the aggregates was $15^{\circ} \mathrm{C}$ above the mixing temperature. The compaction was performed by a SUPERPAVE® gyratory compactor (brand SERVOPAC) with rotation angle of $1.25 \pm 0.02^{\circ}$, rate of 30 revolutions per minute and vertical tension of $600 \mathrm{kPa}$. The mixtures met the volumetric parameters established by the SUPERPAVE® methodology and the Brazilian standard DNIT 031/06-ES (Brasila, 2006) 


\subsection{Permanent deformation tests}

The asphalt mixtures permanent deformation resistance was evaluated in the laboratory through French Rutting Tester (FRT), developed by Institut Français des Sciences et Technologies des Transports, de L'aménagement et des Réseaux - IFSTTAR (in French). The FRT is capable of testing two asphalt mixtures samples (slabs). The slabs dimensions were $180 \mathrm{~mm}$ wide, $50 \mathrm{~mm}$ long, $50 \mathrm{~mm}$ thick. Samples were compacted with a French laboratory-tired compactor until reaching the apparent density established at the design, follows NF-P 98-250-2 French standard (AFNOR, 1997).

The test was performed by the French standard NF-P 98-253-1 (AFNOR, 1993), in which loading of samples is accomplished by applying a 5,000N load onto a $400 \times 8$ Treb Smooth pneumatic tire inflated to $600 \mathrm{kPa}$. During testing, the pneumatic tire passes over the center of the sample twice per second. Test temperature was $60^{\circ} \mathrm{C}$, since the asphalt mixtures will be used as a pavement surface. Rut depths within the FRT are defined by rutting depth (deformation) expressed as a percentage of the original slab thickness.

Before the test, the samples are conditioned and a zero rut depth is defined by loading a sample at ambient temperature for 600 cycles. With the established test temperature $\left(60^{\circ} \mathrm{C}\right)$ readings in the cycles $0,100,300,1,000,10,000$ and 30,000 were performed in 15 points of each slab. The measurement of rutting depth along the cycles is shown in Figure 8.

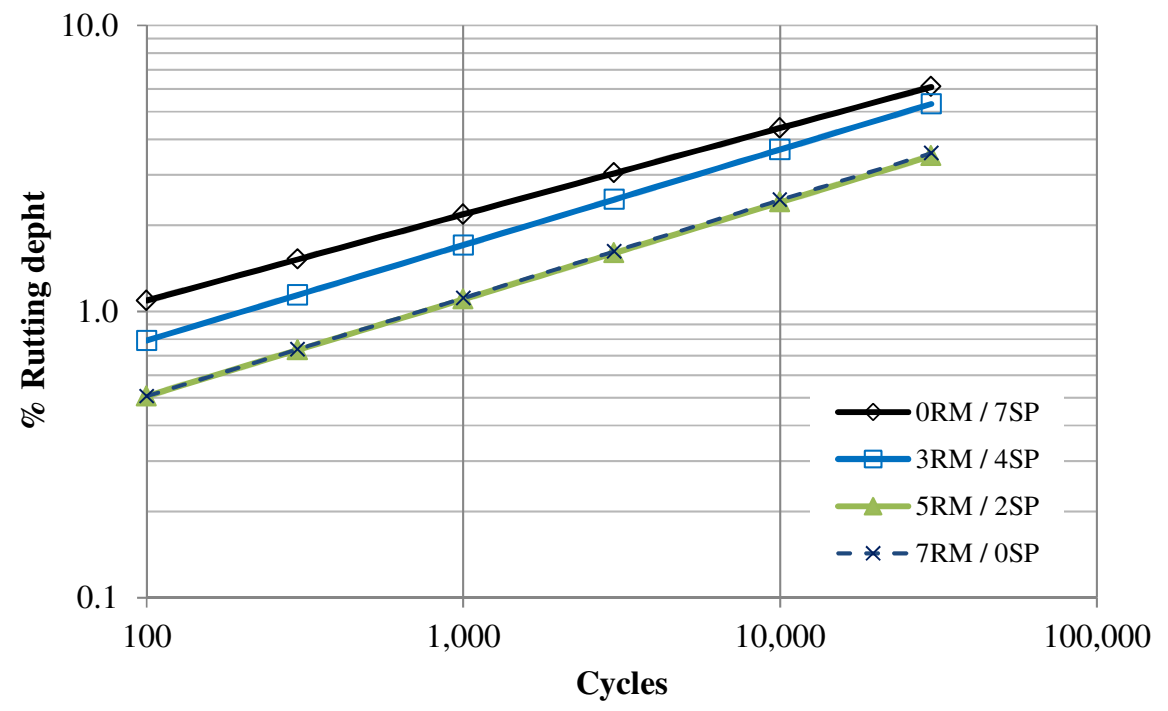

Figure 8. Evolution of the rutting depth along the cycles

The French specifications limit the rutting depth of asphalt mixtures by $10 \%$ in relation to the initial reading, for the standard axis of $130 \mathrm{kN}$, while in Brazil, the standard axis used in the flexible pavements design is $80 \mathrm{kN}$. Considering the most severe condition, according to the French specification, the asphalt mixtures obtained rutting depth of less than $10 \%$. The mixtures with red mud filler presented higher resistance to permanent deformation in relation to the reference mixture, and the mixture M3 (5\% of red mud filler) obtained better results. The red mud insertion as filler for asphalt mixtures improved the performance to permanent deformation in relation to the conventional mixture, with rutting depth reduction, on average, of $12.82 \%$ to $42.63 \%$, related to 30,000 cycles, as presented in Table 6 . 
Table 6 - Asphalt mixtures with red mud rutting depth reduction in relation to conventional mixture

\begin{tabular}{ccccc}
\hline \multirow{2}{*}{ Cycles } & \multicolumn{4}{c}{ Mixtures } \\
& M1 & M2 & M3 & M4 \\
\cline { 2 - 5 } & \multicolumn{4}{c}{ Rutting (depht) (\%) } \\
\hline 100 & 1.09 & 0.79 & 0.51 & 0.51 \\
300 & 1.52 & 1.14 & 0.73 & 0.74 \\
1,000 & 2.19 & 1.71 & 1.10 & 1.11 \\
3,000 & 3.05 & 2.66 & 1.60 & 1.62 \\
10,000 & 4.38 & 3.68 & 2.41 & 2.46 \\
30,000 & 6.10 & 5.31 & 3.50 & 3.58 \\
Rutting depth reduction at 30,000 cycles (\%) & - & 12.82 & 42.63 & 41.30 \\
\hline
\end{tabular}

\section{CONCLUSION}

This laboratory studies evaluated the application of the bauxite processing waste, the red mud, as filler in dense asphalt mixtures in relation to the increase in resistance to permanent deformation. Asphalt mixtures composed of 3\% (M2 - 3RM / 4SP), 5\% (M3 - 5RM / 2SP) and 7\% (M4 - 7RM / 0SP) of red mud were produced. A mixture with 7\% (M1 - 0RM / 7SP) of stone powder was used as reference for comparison. The red mud was characterized by the following tests: X-ray diffraction, fluorescence, specific mass, laser granulometry and Scanning Electron Microscopy. The granulometry test showed that the red mud can be used as filler $(0.075 \mathrm{~mm})$. The $\mathrm{pH}$ of the waste is in accordance to standards established in the Brazilian standard regarding toxicity. However, the presence of vanadium pentoxide $\left(\mathrm{V}_{2} \mathrm{O}_{5}\right)$, even in small portions $(0.20 \%)$, characterizes it as toxic (Class I - hazardous waste). The evaluation of the resistance to permanent deformation showed that all the mixtures containing red mud as filler had superior performance with reduction of the rutting depth of 12.63 to 42.63 in relation to the reference mixture at 30,000 cycles. The mixture with 5\% red mud (M3) presented the best performance with rutting depth at 30,000 cycles of 3.50\%. It is possible that the red mud has acted on the thermal susceptibility of the asphalt. The lower asphalt content obtained for asphalt mixtures was no expected considering the fine particles size. The lower asphalt content could have influenced the permanent deformation results. As a result, this study showed the viability of reinserting the red mud in the production chain and contributed for the mitigation of its disposal and reuse problems, as alternative material of possible applied in the road infrastructure. Despite the use of industrial residues in order to replacement natural or industrial materials can represent an advantage in relation to waste management; red mud is as a hazardous waste. Also, for use asphalt mixtures with red mud in pavements, in large scale, some tests need to be done in order to evaluate the potential pollutants or contaminants that could leach during the pavement life. Also, was observed that to use this residue in large scale to produce asphalt mixtures in asphalt plants, some important regards must be emphasized as a procedure to be followed. For example, depends on the air humidity, red mud tends to form clumps, which is a problem that will affect the mixture performance on the field. To use the residue in large scale a sprayer has to mount in the asphalt plant. Also, the material must be conserved dried.

\section{REFERENCES}

AASHTO (2011) M 323 - Standard specification for Superpave volumetric mix design. American Association of State Highway and Transportation Officials. Washington, D.C., USA.

AASHTO (2012) R 35-12 - Standard practice for Superpave volumetric design for hot-mix asphalt (HMA). American Association of State Highway and Transportation Officials. Washington, D.C, USA.

ABNT (1995) NBR 6502/95 - Rochas e solos. Associação Brasileira de Normas Técnicas. Rio de Janeiro/RJ, Brasil. [In Portuguese]. 
ABNT (2004) NBR 10.004 - Resíduos sólidos - Classificação. Associação Brasileira de Normas Técnicas. Rio de Janeiro/RJ, Brasil. [In Portuguese].

AFNOR (1993) NF-P 98-253-1 - Préparation des mélanges hydrocarbonés, Partie 1: essai d'orniérage. Association Française de Normalisation, AFNOR. France.

AFNOR (1997) NF-P 98-250-2 - Essais relatifs aux chaussées - préparation des mélanges hydrocarbonés, Partie 2: compactage des plaques. Association Française de Normalisation. France.

Ahmad, J.; Abdul Rahman, M. Y. and M. R. Hainin (2011). Rutting evaluation of dense graded hot mix asphalt mixture. International Journal of Engineering \& Technology, IJET-IJENS, v.11 n. 05, p. 56-60.

Al-Shamsi, K.; Hassan, H. F. and L. N. Mohammed (2017). Effect of low VMA in hot mix asphalt on load-related cracking resistance. Construction and Building Materials, v. 149, p. 386-394.

Antunes, M. L. P.; Conceição, F. T. D. and G. R. B. Navarro (2011). Caracterização da Lama Vermelha Brasileira (Resíduo do Refino da Bauxita) e Avaliação de suas Propriedades para Futuras Aplicações. 3 ${ }^{\text {rd }}$ International Workshop Advances in Cleaner Production. São Paulo, Brazil. [In Portuguese].

ASTM (2013) ASTM C 88 - Standard test method for soundness of aggregates by use of sodium sulfate or magnesium sulfate. American Society of Testing and Materials, USA.

ASTM (2012) ASTM C 127 - Standard test method for density, relative density (specific gravity), and absorption of coarse aggregate. American Society of Testing and Materials, USA.

ASTM (2006) ASTM C 131 - Standard test method for resistance to degradation of small-size aggregate by abrasion and impact in the Los Angeles machine. American Society of Testing and Materials, USA.

ASTM (2013) ASTM D 5 - Standard test method for penetration of bituminous materials. American Society of Testing and Materials, USA.

ASTM (2014) ASTM D 36 - Standard test method for softening point of bitumen (ring-and-ball apparatus). American Society of Testing and Materials, USA.

ASTM (2013) ASTM D 4402 - Standard test method for viscosity determination of asphalt at elevated temperatures using a rotational viscometer. American Society of Testing and Materials, USA.

Bertocchi, A. F; Ghiani, M.; Peretti, R. and A. Zucca (2006). Red mud and fly ash for remediation of mines sites contaminated with As, Cd, Cu, Pb e Zn. Journal of Hazardous Materials , v.134, p. 112-119.

Brasil (1998). DNER ME 083/98 - Agregados - análise granulométrica. Norma rodoviária. Departamento Nacional de Estradas de Rodagem/Departamento Nacional de Infraestrutura de Transportes. Rio de Janeiro/RJ, Brasil. [In Portuguese].

Brasil (2006a). DNIT 031/06-ES - Pavimentos flexíveis - concreto asfáltico, Especificação de serviço. Norma rodoviária. Departamento Nacional de Infraestrutura de Transportes. Rio de Janeiro/RJ, Brasil. [In Portuguese].

Brasil (2006b). DNIT 095/06-EM - Cimentos asfálticos de petróleo - Especificação de material. Norma rodoviária. Departamento Nacional de Infraestrutura de Transportes. Rio de Janeiro/RJ, Brasil. [In Portuguese].

Brasil (2016). Sumário Mineral 2015. Departamento Nacional de Produção Mineral. ISSN 0101 2053, 2016. [In Portuguese].

Brown, E. R.; Kandhal, P. S. and J. Zhang (2001). Performance testing for hot mix asphalt. NCAT Report n. 01-05. National Center for Asphalt Technology - NAPA. Auburn/AL, USA.

Brunori, C.; Cremisini C.; Massanisso, P.; Pinto, V. and L. Torricelli (2005). Reuse of a treated red mud bauxite waste: studies on environmental compatibility. Journal of Hazardous Materials, v.117, p. 55-63.

DOI: 10.1016/j.jhazmat.2004.09.010.

Chadbourn, B. A.; Skok, E. L.; Newcomb, D. E.; Crow, B. L. and S. Spindler (1999). The effect of voids in mineral aggregate (VMA) on hot-mix asphalt pavements. Final Report n. MN/RC - 2000-13. University of Minnesota, Minneapolis, MN, USA.

DNER (1995) - DNER-ME 084 - Agregado miúdo - Determinação da densidade real. Departamento Nacional de Estradas de Rodagem, Rio de Janeiro, Brasil. [In Portuguese].

DNER (1994) - DNER-ME 085 - Material finamente pulverizado - Determinação da massa específica real. Departamento Nacional de Estradas de Rodagem, Rio de Janeiro, Brasil. [In Portuguese].

FHWA (2001). Superpave mixture: design guide. Federal Highway Administration. United States Department of Transportation. Westrack Forensic Team Consensus Report. Washington, D.C., USA.

Habashi, F. (2005). A short history of hydrometallurgy. Hydrometallurgy, v. 79, p. 15-22. DOI: 10.1016/j.hydromet.2004.01.008.

Hanumanth Rao, C. V.; Ganapati Naidu, G.; Satyanayarana, C. H. V. and S. Adiseshu (2012). Application of GGBS stabilized red mud in road construction. Journal of Engineering (IOSRJEN), v. 2, n. 8, p. 14-20. ISSN: 2250-3021.

Hildebrando, E. A.; Souza, J. A. S.; Angélica, R. S. and R. F. Neve (2013). Application of bauxite waste from Amazon region in the heavy clay industry. Materials Research, v. XVI, n. 6, p. 1418-1422. DOI: 10.1590/S1516-14392013005000145.

Hind, R. A.; Bhargava, S. K. and S. C. Grocott (1999). The surface chemistry of Bayer process solids: a review. J. Colloids and surfaces A: Physicochemical and engineering aspects, 146, 1999. p. 359-374. DOI: 10.1016/S0927-7757(98)00798-5.

Hislop, P. W. and K. J. Coree (2000). VMA as a design parameter in hot-mix asphalt. Proceedings Mid-Continent Transportation Symposium 2000. Center for Transportation Research and Education, Iowa State University, USA.

Jitsangiam, P. and H. R. Nikraz (2013). Sustainable use of coarse bauxite residue for alternative roadway construction materials. Australian Journal of Civil Engineering, v. 11, n. 1, p. 1-12.

DOI: $10.7158 / 14488353.2013 .11463987$. 
Kavas, T. (2006). Use of boron waste as a fluxing agent in production of red mud brick. Building and Environment, v. 41, p. 1779-1783. DOI: 10.1016/j.buildenv.2005.07.019.

Komnitsas, K.; Bartzas, G. and I. Paspaliaris (2004). Efficiency of limestone and red mud barriers: laboratory column studies Miner. Minerals Engineering, v. 17, p. 183-194. D0I: 10.1016/j.mineng.2003.11.006.

Li, L.Y. (1998). Properties of red mud tailings produced under varying process conditions. Journal of Environmental Engineering, v. 124(3); 254-264. DOI: 10.1061/(ASCE)0733-9372(1998)124:3(254).

Li, Y. (2014). Digital mix design for performance optimization of asphalt mixture. Thesis. Virginia Polytechnic Institute and State University, Virginia, USA.

Mccormick, P. G.; Pícaro, T. and P. A. I. Smith (2000). Mechanochemical treatment of high silica bauxite with lime. Minerals Engineering, v. 15, p. 211-214. DOI: 10.1007/978-3-319-48179-1_5.

Menzie, W. D.; Barry, J. J.; Bleiwas, D. I.; Bray, E. L.; Goonan T. G. and G. Matos (2010). The global flow of aluminum from 2006 through 2025. United States Department of the Interior United States Geological Survey, Reston, Virginia, USA.

Motta, L. M. G. and L. M. F Leite (2000). Efeito do fíler nas características mecânicas das misturas asfálticas. In: XI PANAM. Brasil, p. 09-19. [In Portuguese].

Nevelt, G. and H. Thanfold (1988). Evaluation of the resistance to deformation of different road structures and asphalt mixtures determined in the pavement-rutting tester. Proceeding of the Association of Asphalt Paving Technologists, vol. 57, p. 320-345.

Power, G.; Gräfe, M. and C. Klauber (2009). Review of current bauxite residue management, disposal and storage: practices, engineering \& science. The Commonwealth Scientific and Industrial Research Organization (CSIRO). CSIRO document DMR3608. Austrália.

Sampaio, J. A.; Andrade, M. C. and A. J. B. Dutra (2005). Bauxita. Rochas \& Minerais Industriais. Ed. Luz, Rio de Janeiro, Brasil. ISBN 85-7227-204-6. [In Portuguese].

Sousa, J. B.; Solaimanian, M. and S. L. Weissman (1994). Development and use of the repeated shear test (constant height): an optional Superpave mix design tool - SHRP-A-698. Strategic Highway Research Program. National Council. Washington, D.C., USA.

Sutar, H.; Mishra, S. C.; Sahoo, S. K.; Chakraverty, A. P. and H. S. Maharana (2014). Progress of red mud utilization: an overview. American Chemical Science Journal, v. 4(3), 255-279.

DOI: $10.9734 / \mathrm{ACS} / 2014 / 7258$.

Tabereaux, T. Alton (2010). Hungarian red mud disaster: addressing environmental liabilities of alumina, residue storage \& disposal. Series the discovery, commercialization, and development of the aluminum industry in France. Light Metal Age, v. 68, p. 22-24.

Tigdemir, M. (2008). Dynamic permanent deformation testing of asphalt mixes and deformation waveform analysis. Indian Journal of Engineering \& Materials Sciences, v. 15, p. 29-35. ISSN 0971-4588.

U.S. Geological Survey (2016). Mineral Commodity Summaries. Available in: https://minerals.usgs.gov/minerals/pubs/commodity/bauxite/mcs-2016-bauxi.pdf

Wang, S.; Ang, H. M. and M. O. Tadé (2008). Novel applications of red mud as coagulant, adsorbent and catalyst for environmentally benign processes. Chemosphere, v. 72, p. 1621-1635.

DOI: 10.1016/j.chemosphere.2008.05.013.

$\mathrm{Xu}$, T.; Wang, H.; Li, Z. and Y. Zhao (2014). Evaluation of permanent deformation of asphalt mixtures using different laboratory performance tests. Construction and Building Materials , v.53, p. 561-567.

DOI: 10.1016/j.conbuildmat.2013.12.015.

Wessling, D. H.; L. P. Specht and Ceratti, J. A. P. (2003). Estudo laboratorial do comportamento de misturas em concreto asfáltico com diferentes tipos de filers. 34a Reunião Anual de Pavimentação, Associação Brasileira de Pavimentação (ABPv). Campinas, S.P., Brasil. [In Portuguese].

Yang, H.; Chenb, C.; Panb, L.; Lub, H.; Sunb, H. and X. Hub (2009). Preparation of double-layer glass-ceramic/ceramic tile from bauxite tailings and red mud. Journal of the European Ceramic Society, v. 29, p. 1887-1894. DOI: DOI: 10.1016/j.jeurceramsoc.2009.01.007.

Yang, J. and B. Xiao (2008). Development of unsintered construction materials red mud wastes produced in the sintering alumina process. Construction and Building Materials, n. 22, p. 2299-2307.

DOI: 10.1016/j.conbuildmat.2007.10.005

Yang, Q. and J. Ning (2011). The environmental influence of asphalt pavement and countermeasures. Energy Procedia, v. 5, p. 2432-2436. DOI: 10.1016/j.egypro.2011.03.418. 